\title{
The utilization of okra leaves as an agricultural waste for the removal of $\mathrm{As}(\mathrm{III})$ and $\mathrm{As}(\mathrm{V})$
}

\author{
Khaskheli M.I. ${ }^{1}$, Chandio Z.A. ${ }^{2 *}$, Khan S. ${ }^{3}$, Khokhar F.M. ${ }^{4}$, Memon A.G. ${ }^{5}$, Jatoi W.B. ${ }^{6}$, Khokhar L.A.K. ${ }^{4}$, and Shahani N.K. ${ }^{6}$ \\ ${ }_{1}^{1}$ Department of Chemistry, Government College University Hyderabad, Pakistan \\ 2Department of Chemistry, Shaheed Benazir Bhutto University, Shaheed Benazirabad, Pakistan \\ ${ }^{3}$ Department of Biochemistry, Shah Abdul Latif University, Khairpur Mir's, Pakistan \\ ${ }^{4}$ Institute of Advanced Research Studies in Chemical Sciences, University of Sindh, Jamshoro, Pakistan \\ ${ }^{5}$ Dr. M. A. Kazi Institute of Chemistry, University of Sindh, Jamshoro 76080, Pakistan \\ ${ }^{6}$ Institute of Chemistry, Shah Abdul Latif University, Khairpur Mir's, Pakistan \\ Received: 02/04/2020, Accepted: 21/04/2021, Available online: 25/06/2021 \\ *to whom all correspondence should be addressed: e-mail: Zaheerchandio1@yahoo.com \\ https://doi.org/10.30955/gnj.003321
}

\section{Graphical abstract}

Visual Abstract
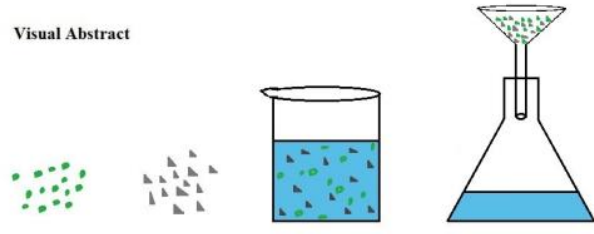

FAAS

bstract

In the present study the sorption efficiency of okra leave sorbent for $\mathrm{As}(\mathrm{III})$ and $\mathrm{As}(\mathrm{V})$ is demonstrated. Sorption reaction is $\mathrm{pH}$ and time dependent. The sorbent shows maximum removal of $\mathrm{As}(\mathrm{III})$ and $\mathrm{As}(\mathrm{V})$ at $\mathrm{pH} 7$ and $\mathrm{pH} 6$ respectively and equilibrium was achieved at 180 minutes. In isotherm study experimental data were explained by Freundlich and Flory-Huggins models. Maximum sorption capacities calculated by Freundlich Isotherm were 5672.0 $\mu \mathrm{g} \mathrm{g}^{-1}$ and $13160 \mu \mathrm{g} \mathrm{g}^{-1}$ for $\mathrm{As}(\mathrm{III})$ and $\mathrm{As}(\mathrm{V})$ respectively. Psuedo-second order rate equation and Morris-Weber equation explained the kinetics of sorption reaction. Due to the presence of heterogeneous active sites on the sorbent, surface sorption as well as intra-particle diffusion occurred. Thermodynamically, sorption reaction was endothermic in nature and proceeded spontaneously. Desorption study revealed that $89.82 \%$ of $\mathrm{As}(\mathrm{III})$ and $97.11 \%$ of $\mathrm{As}(\mathrm{V})$ were removed with $1 \mathrm{M} \mathrm{HCl}$.

Keywords: Okra, sorption, arsenic, equilibrium, thermodynamics.

\section{Introduction}

Arsenic, a metalloid, is present in air, soil, water, minerals, rocks and biota with various concentrations (Chowdhury and Mulugan, 2011). Arsenic is the $20^{\text {th }}$ most abundant element in the earth's crust, 14th in sea water and 12th in the human body (Shafique et al., 2012). Since its discovery in 1250 A.D., arsenic has been used in medicines, agriculture, metallurgy and electronics. It is estimated that nearly $22 \%$ of arsenic production is used in agricultural chemicals (Chen et al., 2010). The solubility of arsenic depends upon $\mathrm{pH}$, redox condition, temperature and solution composition (Giri et al., 2011). It is nonbiodegradable and detrimental to the flora and fauna. More than 300 species of arsenic bearing minerals exist in nature (Lorenzen et al., 1995). Mostly natural processes (e.g., geochemical reactions and volcanic emissions) and anthropogenic activities (e.g., mining, industrial, chemical waste and arsenical pesticides) are the major causes of arsenic pollution (Haron et al., 1999; Huang and Fu, 1984; Maheshwari and Murugesan, 2011).

The existence of arsenate, arsenite, monomethyl (MMA) arsenic acid and dimethyl (DMA) arsenic acid depends upon the environment (i.e., $\mathrm{pH}$, Eh) and microbial activity (Jing et al., 2009). Generally, stable inorganic species of arsenic are found with oxidation states like -3 (arsine gas $\mathrm{AsH}_{3}$ ), $\mathrm{O}$ (crystalline/metallic arsenic), +3 (arsenite), and +5 (arsenate). A crystalline form of arsenic is very rarely found. The favorable conditions for arsine gas, arsenite (ground water) and arsenate (surface water) are extreme reducing, mild reducing and oxygenated environments respectively. Generally inorganic arsenic compounds have higher toxicities than organic arsenicals (Chen et al., 1994; Li et al., 1995). As(III) compounds are (25-60 times) more toxic than As(V) compounds (Aryal et al., 2010). As(III) which is more mobile is difficult to remove as compared to $\mathrm{As}(\mathrm{V})$, which exists predominantly as deprotonated oxyanions $\left(\mathrm{H}_{2} \mathrm{AsO}_{4}{ }^{1-}\right.$ or $\left.\mathrm{HAsO}_{4}{ }^{2-}\right)$. Very minute quantity of arsenic is required for the human healthy growth. Above the recommended concentration, arsenic disturbs the regular metabolic activity of living organisms. The accumulation of arsenic compounds in food, even at very low concentration causes different diseases in plant, animal and human life (Pokhrel et al., 2008). It has mutagenic and tetratogenic capacity for human health (ATSDR 1990) severe arsenic poisoning 
causes even to death. In mammals, arsenic diseases are due to the reaction with sulfhydryl groups of enzymes (Korte et al., 1991). Arsenic poisoning causes heart disease, keratosis, hyperpigmentation, burning sensation of eyes, anaemia, liver fibrosis, neuropathy, solid swelling of legs, gangrene of toes, lung cancer, skin cancer, liver cancer, bladder cancer, kidney cancer and prostate (National Research Council, Report: 1999; Sari et al., 2011; Smith et al., 2004; Tuzen et al., 2009).

To handle water pollution by arsenic, various conventional processes such as precipitation, coagulation, solvent extraction, ion-exchange and reverse osmosis etc. have been employed (Khaskheli et al., 2011). Considering the advantages and disadvantages of other metal removal methods, sorption has been emerged as an alternative. In the past 20 years sorption has gotten much importance because in this technique, various types of sorbents are frequently used (Biswas et al., 2008). Sorption has many different advantages such as high metal binding efficiency, short operating time, reusability of biomass, improved selectivity for specific metals of interest, no production of secondary toxic compounds (Kamala et al., 2005; Rahman et al., 2008). Further, it has practical applicability for small scale industries.

The present work demonstrates the uptake efficiency of okra (Abelmoschus esculentus) leaves for the removal of arsenic(III) and arsenic(V) from aqueous solution. Different parameters like $\mathrm{pH}$, contact time and sorbate amount were optimized. Freundlich and Florry-Huggins models were used to describe equilibrium isotherms. For understanding the sorption mechanism of arsenic species on okra leaves, the observed experimental data were kinetically and thermodynamically analyzed.

\section{Experimental procedure}

\subsection{Reagents and equipments}

In the experiments all reagents used were of analytical grade or equivalent. Stock solutions (1000 $\mathrm{mg} \mathrm{L}^{-1}$ ) of As(III) and $\mathrm{As}(\mathrm{V})$ were prepared by dissolving calculated amounts of $\mathrm{As}_{2} \mathrm{O}_{3}$ (Poole, England) and $\mathrm{Na}_{3} \mathrm{AsO}_{4}$ (Merck, Germany) in de-ionized water respectively. Working solutions for experiments were freshly prepared from the stock solutions. For adjusting the $\mathrm{pH}$, buffers of acetic acid $\left(\mathrm{CH}_{3} \mathrm{COOH}\right)$, sodium acetate $\left(\mathrm{CH}_{3} \mathrm{COONa}\right)$, potassium chloride $(\mathrm{KCl})$, hydrochloric acid $(\mathrm{HCl})$ and sodium hydroxide $(\mathrm{NaOH})$ were used. Reducing agent for arsenic was prepared by mixing the $0.2 \% \mathrm{w} / \mathrm{v}$ sodium borohydride $\left(\mathrm{NaBH}_{4}\right)$ (Darmstadt company, Merck, Germany) in $0.05 \%$ w/v NaOH (Fisher scientific UK).

During sorption experiments $\mathrm{pH}$ of all solutions was measured by Thermo Scientific Orion 5 Star (8102BNUWP; made in USA) $\mathrm{pH}$ meter. To facilitate the reaction between sorbent and sorbate shaking incubator model 1-40000 Irmeco $\mathrm{GmbH}$ (made in Germany) was used. Arsenic concentration was analyzed by Atomic Absorption Spectrometer (Analyst 800 Perkin Elmer, USA) connected with a Flow Injection System for hydride generation (FIAS 100 Perkin Elmer, USA). Atomic Absorption Spectrometer equipped with a hallow cathode lamp having current $\mathrm{mA}$
18, wavelength $\mathrm{nm} \mathrm{193.7,} \mathrm{energy} \mathrm{40,} \mathrm{band} \mathrm{width} 0.7 \mathrm{~nm}$ (made in Singapore) and Quartz Tube Atomizer (Universal QAT, part number B300 - 0350, USA) were used.

\subsection{Collection and preparation of biomass}

The green okra leaves (sorbent material) obtained from the agricultural farm located in Kingri, District Khairpur Mirs, Sindh, Pakistan. In order to remove dust and extraneous particles, okra leaves were washed with tap and deionized water. Then the leaves were put in oven for drying at $60^{\circ} \mathrm{C}$ for $24 \mathrm{~h}$. The dried sorbent material was ground and sieved in range of $0.125-0.42 \mathrm{~mm}$ particle size. After the selection of particle size $(0.125 \mathrm{~mm}) 1 \mathrm{~g}$ of the desired particle size of the sorbent was treated with $25 \mathrm{~mL}$ of $1 \mathrm{M} \mathrm{NaOH}$ at 30 ${ }^{\circ} \mathrm{C}$, agitation at $250 \mathrm{rpm}$ for 15 minutes. Then base treated sorbent material was washed with de-ionized water till filtrate became colorless. In the last, again washed material was dried in oven at $80^{\circ} \mathrm{C}$ for $10 \mathrm{~h}$.

\subsection{Batch sorption procedure}

The metal sorption behavior of okra sorbent was investigated using batch equilibrium experiments. The calculated amount of okra sorbent was added to $10 \mathrm{~mL}$ of arsenic solution in $100 \mathrm{~mL}$ stopper conical flask and agitated in an electric thermostatic reciprocating shaker at $100 \mathrm{rpm}$ for desired contact time. The sorption reactions were carried out at $30,35,40$ and $45^{\circ} \mathrm{C}$. The equilibrium time was determined by taking out the samples from electrical thermostatic shaker at different times. After filtering the samples, the arsenic concentration in the filtrate was analyzed by Absorption Spectrometer connected to FIAS system. The stated experimental procedure was repeated for the optimization of different parameters- biomass dosage (0.05 - $0.3 \mathrm{~g})$, sorbent particle size $(0.125-0.42 \mathrm{~mm}$ ) contact time ( $0-1440 \mathrm{~min})$, agitation speed (50 - $250 \mathrm{rpm})$, volume of test solution $(10-50 \mathrm{~mL})$, metal concentration $\left(0.01-50 \mathrm{mg} \mathrm{L}^{-1}\right)$ and $\mathrm{pH}(1-10)$.

\section{Results and discussion}

\subsection{Sorbent characterization}

\subsubsection{EDX analysis}

To carry out further experiments for the method development, it is very necessary to characterize the sorbent nature before and after the sorption of arsenic ions. For Energy Dispersive X-ray (EDX) analysis, BRUKER XFLASH 4010 133ev (made in Germany) was used. In Fig.1a and $1 \mathrm{~b}$ elements are shown on the surface of untreated and arsenic treated sorbent respectively. Fig. 1a contains oxygen, calcium and carbon. In Fig. $1 \mathrm{~b}$ the presence of small peak of arsenic confirms the sorption of arsenic.

\subsubsection{Fourier transform infrared spectroscopy (FT-IR) analysis}

The FT-IR study demonstrates the changes in vibrational frequencies of functional groups present in the okra sorbent before and after the sorption of arsenic ions. In the Fig. 2 the spectra of untreated and arsenic treated sorbent are taken. The frequency of spectra was maintained in the range of $500-4000 \mathrm{~cm}^{-1}$. The recorded changes in the frequencies are shown in Table 1 . The peaks at $3301 \mathrm{~cm}^{-1}$ and $2847-2908 \mathrm{~cm}^{-1}$ attributed to the stretching of $\mathrm{O}-\mathrm{H}$ 
hydrogen bonding (alcohol or phenol) showed a shift for both $\mathrm{As}(\mathrm{III})$ and $\mathrm{As}(\mathrm{V})$ loaded sorbent. The appearance of new peaks at $1728 \mathrm{~cm}^{-1}$ and $1221 \mathrm{~cm}^{-1}$ and disappearance of peak at $1413 \mathrm{~cm}^{-1}$ in $\mathrm{As}(\mathrm{V})$ loaded sorbent indicates the involvement of $\mathrm{C}=\mathrm{O}, \mathrm{C}-\mathrm{O}$ (ether or ester) and $\mathrm{C}-\mathrm{H}$ respectively for $A s(V)$ ions retention. The change in the vibrational frequencies at $1000 \mathrm{~cm}^{-1}$ and $1147 \mathrm{~cm}^{-1}$ for $\mathrm{As}(\mathrm{III})$ and $\mathrm{As}(\mathrm{V})$ loaded okra sorbent demonstrate the role of $\mathrm{C}-\mathrm{O}$ (alcohol) and $\mathrm{C}-\mathrm{O}$ (ether or ester) respectively in the sorption process.

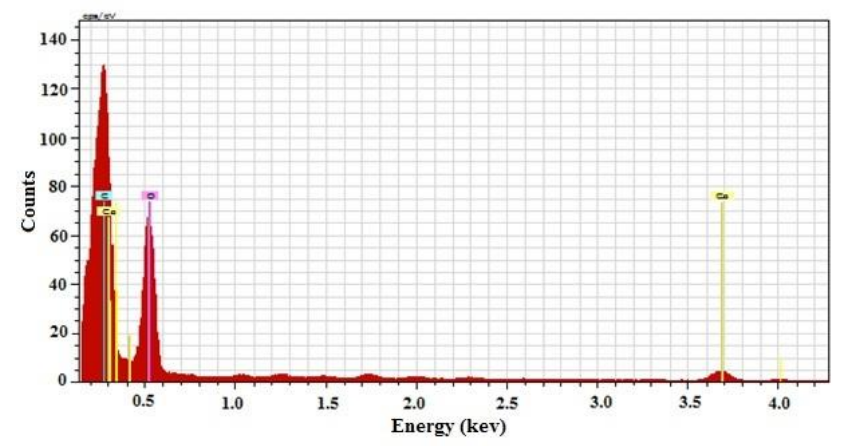

Figure 1a. EDX of okra leaves before arsenic retention

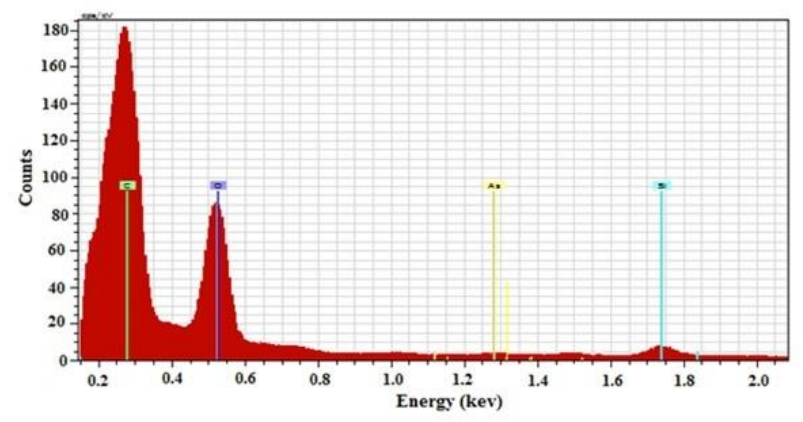

Figure 1b. EDX of okra leaves after arsenic retention

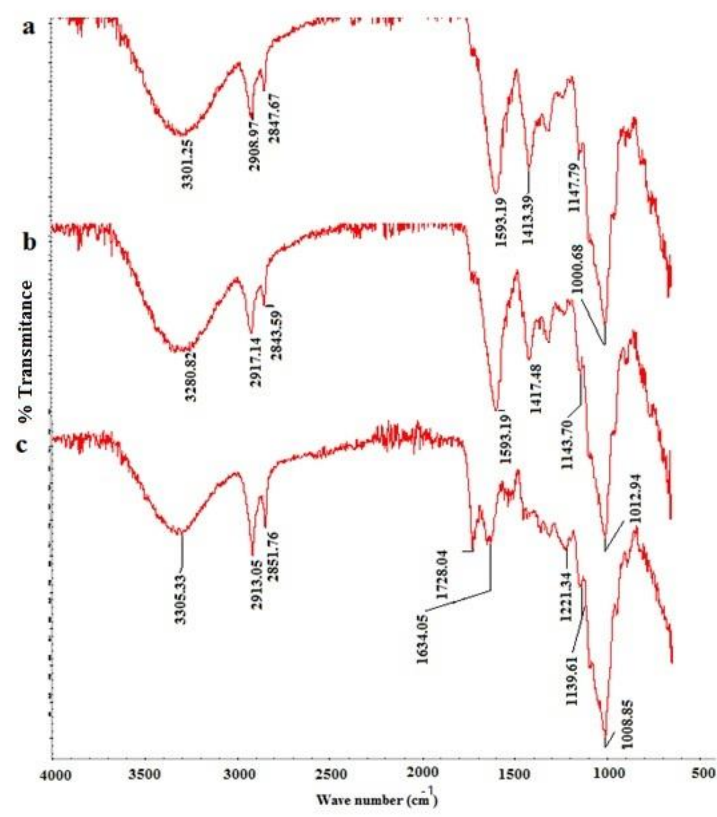

Figure 2.FT-IR spectra of (a)-okra leaves (b)-As(III)-loaded okra leaves (c)-As(V) loaded okra leaves

\subsection{Effect of $p H$}

During the $\mathrm{pH}$ study, $\mathrm{pH}$ range of 1-10 was maintained. The effect of $\mathrm{pH}$ on the sorption of $\mathrm{As}(\mathrm{III})$ and $\mathrm{As}(\mathrm{V})$ on okra sorbent is shown in Fig. 3. It was observed that maximum sorption of both arsenic species was seen in the range of $\mathrm{pH} 6.0$ - 7.0. Such type of sorption trend is also reported in the literature (Aniruthan et al., 2007; Ghimiri et al., 2002).

In case of $\mathrm{As}(\mathrm{III})$ at the mentioned $\mathrm{pH}$ mono-anionic $\left(\mathrm{H}_{2} \mathrm{AsO}_{3}{ }^{-}\right)$specie is considered as responsible for the sorption and substitute hydroxyl ions or water molecules. $\mathrm{H}_{3} \mathrm{AsO}_{4}, \mathrm{H}_{2} \mathrm{AsO}_{4}{ }^{-}, \mathrm{HAsO}_{4}{ }^{2-}$ and $\mathrm{AsO}_{4}{ }^{3-}$ are the dominant $\mathrm{As}(\mathrm{V})$ species in $\mathrm{pH}$ ranges of $<2.26,2.26-6.76,6.76-11.29$ and $>11.29$ respectively (Su et al., 2010). A small decrease in sorption in alkaline $\mathrm{pH}$ can be attributed to the repulsion created between the anionic species of arsenic and negatively charged sorbent.

Table 1. FT-IR absorption bands and assignments for okra leaves and arsenic loaded okra leaves

\begin{tabular}{cccc}
\hline & IR peak frequency $\left(\mathbf{c m}^{-1}\right)$ & & Assignment \\
\cline { 1 - 3 } Okra leaves & $\begin{array}{c}\text { Okra leaves loaded } \\
\text { with } \mathbf{A s}(\mathbf{I I I})\end{array}$ & $\begin{array}{c}\text { Okra leaves loaded } \\
\text { with } \mathbf{A s}(\mathbf{V})\end{array}$ & Hydrogen bond O-H stretching (phenols or alcohols) \\
\hline 3301.25 & 3280.82 & 3305.33 & C-H stretching (alkane) \\
\hline 2908.97 & 2917.14 & 2913.05 & C=O stretching \\
\hline 2847.67 & 2843.59 & 2851.76 & C=C bending (aromatic) \\
\hline 1593.19 & - & 1728.04 & O-H bending (carboxylic acid) \\
\hline 1413.39 & 1593.19 & 1634.05 & C-O stretching (ether or ester) \\
\hline 1147.79 & 1417.00 & - & C-O stretching (alcohol) \\
\hline 1000.68 & - & 1221.34 &
\end{tabular}




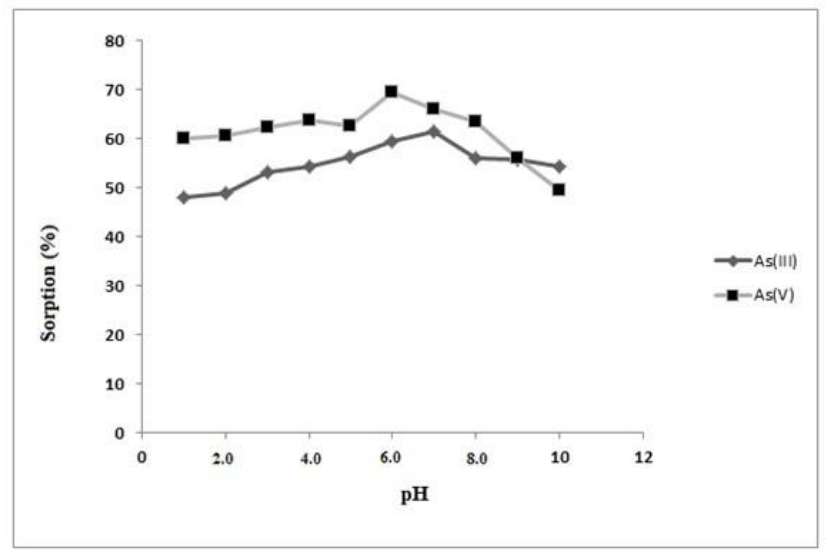

Figure 3. Effect of $\mathrm{pH}$ on the sorption of $\mathrm{As}(\mathrm{III})$ and $\mathrm{As}(\mathrm{V})$

\subsection{Effect of biomass concentration}

Amount of sorbent has key role in the sorption process. It affects the \% sorption of metal ions. By maintaining all other parameters, the amount of okra leave was varied in the range of $0.1-0.6 \mathrm{~g}$. Fig. 4 shows that there is a slight increase in \% sorption as amount of biomass increased from $0.1 \mathrm{~g}$ to $0.6 \mathrm{~g}$ for both arsenic species. Thus, for making method economical $0.1 \mathrm{~g}$ of amount was taken for further study.

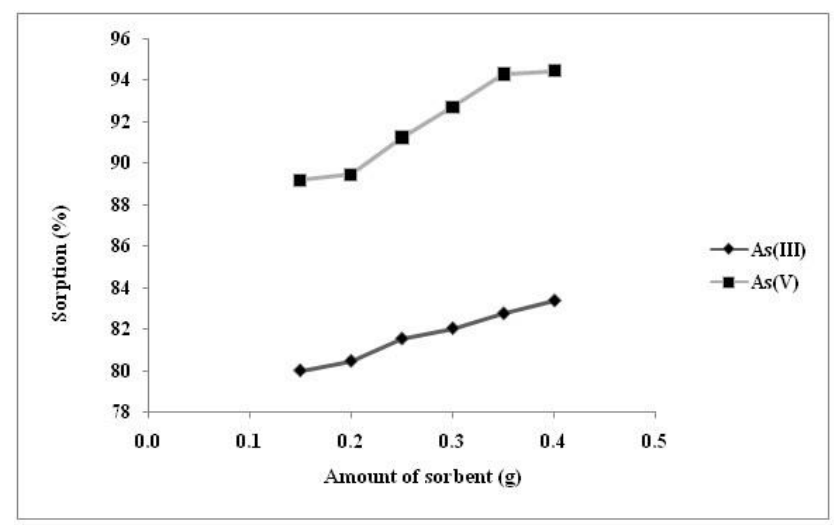

Figure 4. Effect of biomass on the sorption of As(III) and As(V)

Table 2. Regression parameters for the Fruendlich and Florry-Huggins isotherms by using okra leaves as sorbent at different temperatures

\begin{tabular}{|c|c|c|c|c|c|c|c|c|}
\hline \multirow{2}{*}{$\begin{array}{c}\text { Metals } \\
\text { Temperature } \\
\left({ }^{\circ} \mathrm{C}\right)\end{array}$} & \multicolumn{4}{|c|}{ As(III) } & \multicolumn{4}{|c|}{$A s(V)$} \\
\hline & 30 & 35 & 40 & 45 & 30 & 35 & 40 & 45 \\
\hline \multicolumn{9}{|c|}{ Freundlich } \\
\hline$K_{\mathrm{F}}\left(\mu \mathrm{g} \mathrm{g}^{-1}\right)$ & 4070.0 & 5020.0 & 5027.0 & 5672.0 & 3040.0 & 7928.0 & 10660 & 13160 \\
\hline$n$ & 0.880 & 0.954 & 0.945 & 1.094 & 0.798 & 0.753 & 0.746 & 0.737 \\
\hline$r$ & 0.9962 & 0.9958 & 0.9932 & 0.9865 & 0.9992 & 0.9933 & 0.9965 & 0.9959 \\
\hline \multicolumn{9}{|c|}{ Flory-Huggins } \\
\hline$n_{\mathrm{FH}}$ & 5.38 & 5.44 & 5.66 & 5.67 & 6.02 & 4.18 & 3.91 & 3.71 \\
\hline$K_{\mathrm{FH}} 10^{8}$ & 4.71 & 51.5 & 57.2 & 67.6 & 0.80 & 0.89 & 1.16 & 1.24 \\
\hline$\Delta G\left(\mathrm{~kJ} \mathrm{~mol}^{-1}\right)$ & -50.31 & -57.26 & -58.46 & -59.84 & -45.85 & -46.88 & -48.32 & -49.27 \\
\hline$r$ & 0.9539 & 0.9746 & 0.9985 & 0.9274 & 0.9715 & 0.9664 & 0.9623 & 0.9616 \\
\hline \multicolumn{9}{|c|}{$K_{\mathrm{F}}=$ Freundlich Constant. } \\
\hline \multicolumn{9}{|c|}{$n=$ sorption intensity. } \\
\hline \multicolumn{9}{|c|}{$K_{\mathrm{FH}}=$ Flory-Huggins model equilibrium constant. } \\
\hline \multicolumn{9}{|c|}{$\Delta G=$ Gibbs free energy of spontaneity. } \\
\hline$n_{\mathrm{FH}}=$ Flory-Huggir & odel expo & $p r$ & & & & & & \\
\hline
\end{tabular}

\subsection{Effect of contact time}

The effect of reaction time was studied by maintaining the volume of arsenic ions $10 \mathrm{ml}$, arsenic ion concentration 5 $\mathrm{mg} \mathrm{L}^{-1}$, shaking speed $250 \mathrm{rpm}$, the amount of biomass 0.1 $\mathrm{g}$, temperature $30{ }^{\circ} \mathrm{C}$ and $\mathrm{pH} 7.0$ for $\mathrm{As}(\mathrm{III})$ and $\mathrm{pH} 6$ for $\mathrm{As}(\mathrm{V})$. Results in Fig. 5 indicated that up to 180 minutes sorption was continuously increased and then slowly decrease was registered. This trend of decrease in sorption may be due to auto desorption of metal ions.

\subsection{Sorption isotherm study}

Isotherms deal surface properties of a sorbent and its binding forces for metal ions at optimum pressure and temperature. The recorded experimental data were analyzed by the following isotherm models.

\subsubsection{Freundlich adsorption isotherm model}

Freundlich equation is one of the most commonly used isotherm equations. This equation analyzes the experimental data related to the sorption of inorganic and organic compounds on natural as well as synthetic adsorbents. It also explains the nature of sorbents. The following linear form of the Freundlich equation was used (Khaskheli et al., 2017).

$$
\log q_{\mathrm{e}}=\log K_{\mathrm{F}}+\frac{1}{n_{\mathrm{F}}} \log C_{\mathrm{e}}
$$

Where $C_{e}$ is amount of metal ions in the liquid phase at equilibrium, qe amount of metal ions sorbed, $\mathrm{K}_{f}$ (Freundlich Constant) relative sorption capacity and $n$ is sorption intensity. $1 / n>1$ concave isotherm while $1 / n<1$ suggest the presence of convex isotherm Logqe is plotted against logCe. Agreement of the experimental data to the equation indicates that sorbent contains non-equivalent sites (heterogeneous surface). The values of $n$ and $K_{f}$ are 
determined from the slope and intercept. The calculated values of $n$ are less, but near to $1(1 / n>1)$ and supports the concave nature of isotherm (Febrianto et al., 2009). Table 2 shows that $\mathrm{K}_{\mathrm{F}}$ increases with the increase of temperature.

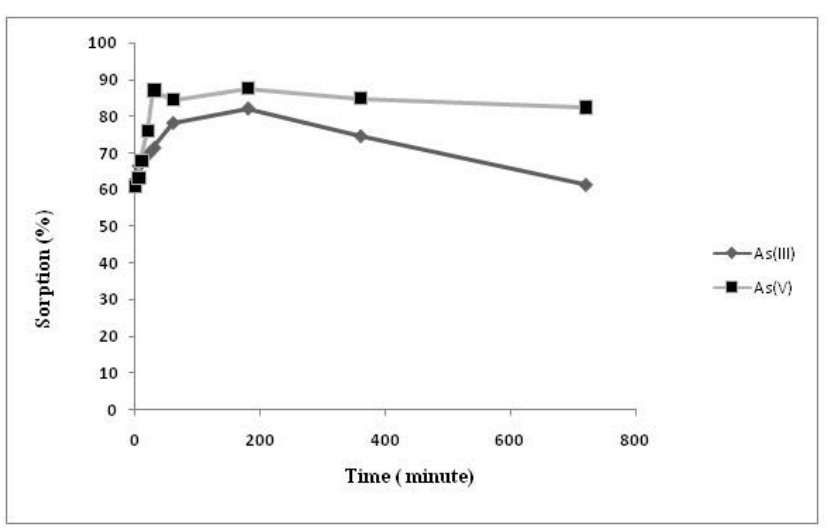

Figure 5. Effect of contact time on the sorption of $A s(I I I)$ and $\operatorname{As}(\mathrm{V})$

\subsubsection{Flory-Huggins adsorption isotherm model}

Flory-Huggins isotherm is used to measure the degree of surface coverage of metal ions on sorbent and change occurred in Gibbs free energy of sorbent (Jnr et al., 2005). Following linear form of the equation is employed for the analysis of the data (Vijayaraghavan et al., 2006).

$$
\begin{aligned}
& \log \frac{\theta}{C_{i}}=\log K_{\mathrm{FH}}+n_{\mathrm{FH}} \log (1-\theta) \\
& \theta=1-\frac{C_{\mathrm{e}}}{C_{i}}
\end{aligned}
$$

Where $C_{e}$ is equilibrium metal ion concentration, $\theta$ is degree of surface coverage, $\mathrm{K}_{\mathrm{FH}}$ is the Flory-Huggins model equilibrium constant and $n_{F H}$ is the Flory-Huggins model exponent represents the number of metal ions of solute occupy active sites of sorbent. The plot of $\log \theta / C_{i}$ versus $\log (1-\theta)$ yields a straight line with high regression values and confirms that experimental data follow the FloryHuggins model. The values of $\mathrm{n}_{\mathrm{FH}}$ and $\mathrm{K}_{\mathrm{FH}}$ are calculated from the intercept and slope of the plot respectively. Table 2 indicates that with the increase of temperature, the number of occupying sorption sites of okra sorbent increases for As(III) and decreases for As(V). Flory-Huggins constant $\mathrm{K}_{\mathrm{FH}}$ is used to calculate the Gibbs free energy of spontaneity $\left(\Delta \mathrm{G}^{\circ}\right)$ by following relationship.

$$
\Delta G^{\circ}=-R T \ln K_{\mathrm{FH}}
$$

Negative values of Gibbs free energy show that process is feasible and spontaneous in nature (Kiran et al., 2008).

\subsection{Kinetic study}

Kinetic study determines the mechanism of sorption time to establish equilibrium. Physical and chemical compositions of okra sorbent have an important role in describing the kinetics of the reaction

\subsubsection{Pseudo second order rate equation}

Ho and McKay (Ho et al., 1998) consider pseudo-secondorder model is best for understanding the kinetics of sorption system. According to this equation rate of sorption reaction depends on the chemical bonding between sorbent and metal ions (Nadeem et al., 2008). Pseudo-second-order rate equation may be written as:

$$
\frac{\mathrm{d} q_{\mathrm{t}}}{\mathrm{d}_{\mathrm{t}}}=k\left(q_{\mathrm{e}}-q_{\mathrm{t}}\right)^{2}
$$

After putting boundary condition values, integrating and rearranging, the following linear equation is obtained.

$$
\begin{aligned}
& \frac{t}{q_{\mathrm{t}}}=\frac{1}{k q_{\mathrm{e}}^{2}}+\frac{1}{q_{\mathrm{e}}} t \\
& h=k q_{\mathrm{e}}^{2}
\end{aligned}
$$$$
t=0, q_{\mathrm{t}}=0 ; t=t, q_{\mathrm{t}}=q_{\mathrm{t}} ;
$$

Where

$k=$ equilibrium rate constant

$h=$ initial adsorption rate

Where $k$ is the equilibrium rate constant which is calculated from slope of the plot $t / q_{\mathrm{t}}$ against $t$. Straight lines of the graph of the both arsenic species along with high values of correlation coefficient (0.99-1) as indicated in Table 3 show that experimental data are well fitted to the equation. From this, it may be deduced that monolayer (chemisorption) of the sorbate is formed by involving valence forces through sharing (covalent bond) or exchange (ionic bond) of electrons or complex compounds may be formed between arsenic ions and okra sorbent. Further, this equation also supports that okra sorbent contains heterogeneous energetic, active sites on the surface.

Table 3. Kinetics parameters for the adsorption of $\mathrm{As}(\mathrm{III})$ and $\mathrm{As}(\mathrm{V})$ on okra leaves at various temperatures

\begin{tabular}{cccccccc}
\hline \multirow{2}{*}{ Metals } & \multicolumn{3}{c}{ Second order rate equation } & \multicolumn{3}{c}{ Intra-particle Diffusion } \\
\cline { 2 - 8 } & $\boldsymbol{K}$ (g/mg.min.) & $\boldsymbol{q}_{\mathrm{e}}$ ( $\left.\mathbf{m g} / \mathbf{g}\right)$ & $\boldsymbol{h}$ (m/g. $\mathbf{m i n})$. & $\boldsymbol{r}$ & $\boldsymbol{k}_{\text {id }}\left(\boldsymbol{\mu}\right.$ mol/g. $\left.\mathbf{m i n}^{\mathbf{0 . 5}}\right)$ & $\boldsymbol{C}$ (intercept) & $\boldsymbol{R}$ \\
\hline $\mathrm{As}(\mathrm{III})$ & 0.0975 & 4.14 & 1.673 & 0.9996 & 1.01 & 42.17 & 0.9762 \\
\hline $\mathrm{As}(\mathrm{V})$ & 0.0487 & 4.62 & 1.040 & 0.9998 & 2.27 & 39.40 & 0.9668 \\
\hline
\end{tabular}

$K=$ equilibrium rate constant.

$q_{\mathrm{e}}=$ sorption capacity of sorbent at equilibrium.

$h=$ initial adsorption rate.

$r=$ correlation coefficient.

$k_{\text {id }}=$ intra-particle diffusion rate constant . 
Table 4. Thermodynamic constants for the sorption of $\mathrm{As}(\mathrm{III})$ and $\mathrm{As}(\mathrm{V})$ on the Okra leaves at different temperatures

\begin{tabular}{|c|c|c|c|c|}
\hline Metals & Temp. (K) & $\Delta G\left(\mathrm{~kJ} \mathrm{~mol}^{-1}\right)$ & $\Delta H\left(\mathrm{~kJ} \mathrm{~mol}^{-1}\right)$ & $\Delta S\left(\mathrm{~J} \mathrm{~mol} \cdot \mathrm{K}^{-1}\right)$ \\
\hline \multirow{4}{*}{$\mathrm{As}(\mathrm{III})$} & 303 & -50.31 & \multirow{4}{*}{128.5} & \multirow{4}{*}{0.596} \\
\hline & 308 & -57.26 & & \\
\hline & 313 & -58.46 & & \\
\hline & 318 & -59.84 & & \\
\hline \multirow{4}{*}{$\mathrm{As}(\mathrm{V})$} & 303 & -45.85 & \multirow{4}{*}{25.07} & \multirow{4}{*}{0.234} \\
\hline & 308 & -46.86 & & \\
\hline & 313 & -48.32 & & \\
\hline & 318 & -49.27 & & \\
\hline
\end{tabular}

\subsubsection{Intra-particle diffusion (Morris-Weber Equation)}

Intra-particle diffusion (Morris-Weber) model (Morris et al., 1963) is used to study the mass transfer resistance on the binding of metal ion to the sorbent.

$$
q t=R d r \sqrt{t}+C
$$

Where qt is sorption capacity of metal ions on sorbent at time $\mathrm{t}(\mathrm{mg} / \mathrm{g})$, Rdr intra-particle diffusion rate constant ( $\mathrm{mg} / \mathrm{g} \cdot \mathrm{min}^{0.5}$ ) and $\mathrm{C}$ intercept which gives the idea of the thickness of the boundary layer. The graph was plotted between qt versus $\mathrm{t}^{1 / 2}$. According to Table 3 , experimental data of $\mathrm{As}(\mathrm{III})$ and $\mathrm{As}(\mathrm{V})$ followed equation up to 180 minutes with $k_{\text {id }}$ values of $1.01 \mathrm{mg} / \mathrm{g} \cdot \mathrm{min}^{0.5}$ and 2.27 $\mathrm{mg} / \mathrm{g} \cdot \mathrm{min}^{0.5}$ respectively. A linear portion of the plot which is not passing through origin reveals that intra-particle diffusion cannot only be attributed the rate limiting step (Chen et al., 2010). It may be explained that mechanism of sorption is complex; Intra-particle diffusion as well as surface adsorption occurs. Similar mechanism of sorption was noticed for the sorption of arsenic on bone char (Chen et al., 2008).

\subsection{Thermodynamic study}

Thermodynamic study helps in estimating the nature and feasibility of the sorption reaction (Iftikhar et al., 2009; Khaskheli et al., 2016; Ladeira et al., 2004). Thermodynamic parameters (enthalpy change, entropy change and Gibbs free energy) were calculated by using the following equation.

$$
\Delta G=\Delta H-T \Delta S
$$

Entropy change $(\Delta S)$ and enthalpy change $(\Delta H)$ were calculated by plotting $\Delta \mathrm{G}$ versus temperature $(\mathrm{T})$. Table 4 shows that negative values of Gibbs free energy $(\Delta G)$ for both $\mathrm{As}(\mathrm{III})$ and $\mathrm{As}(\mathrm{V})$ show the spontaneous (i.e strong forces of sorption control the potential barrier between arsenic and sorbent) nature of sorption. An increase in the negative value of $\Delta G$ with the rise of temperature favors the sorption process. Positive values of $\Delta \mathrm{S}$ for $\mathrm{As}(\mathrm{III})$ and $\mathrm{As}(\mathrm{V})$ demonstrated the increasing randomness at solid / solution interface during the sorption. Positive values of enthalpy change $\Delta \mathrm{H}$ for both species of arsenic indicated the endothermic nature of the sorption process.

\subsection{Desorption/Regeneration study}

To make method efficient and more economical, it is very important to recover sorbent and sorbate. Desorption process yields metals in concerted form, facilitate their disposal and restore the sorbent for effective reuse [39]. With $1 \mathrm{M} \mathrm{HCl}$ maximum recoveries of $\mathrm{As}(\mathrm{III})$ and $\mathrm{As}(\mathrm{V})$ were $89.82 \%$ and $97.11 \%$ respectively.

\subsection{Interference study}

Contaminated real water samples have various electrolytes with different concentrations which affect the sorption process. Thus, the study of electrolytic effect is necessary. The effect of some common electrolytes in the ratios of 1:10 and 1:100 were examined on the removal efficiency of $\mathrm{As}(\mathrm{III})$ and $\mathrm{As}(\mathrm{V})$ with okra leaves. According to histogram Fig. 6a As(III) in the presence of iron(III) with 1:10 and sodium ions with 1:100 showed more than $90 \%$ removal. While $~ 90 \%$ removal capacity of $\mathrm{As}(\mathrm{V})$ (Fig. 6b) was observed with $\mathrm{Fe}(\mathrm{III})$ and $\mathrm{Al}$ ions in 1: 100 ratio.

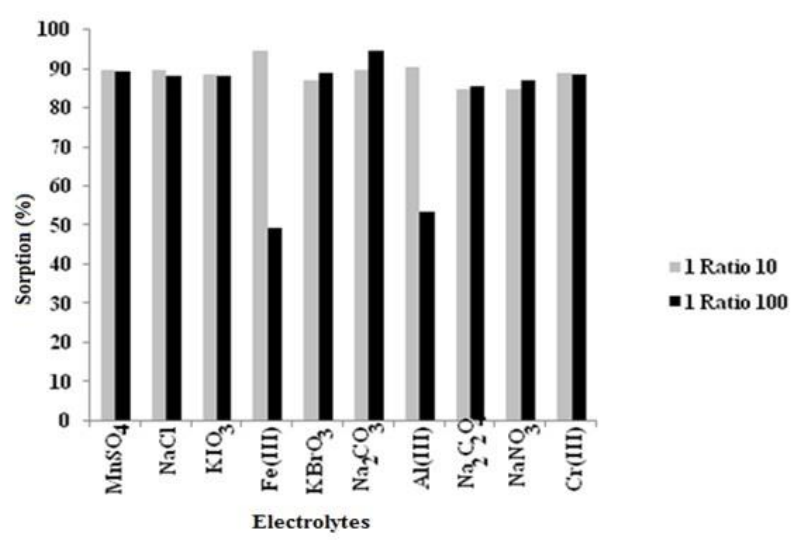

Figure 6a. Electrolytic effect on the sorption of $A s(I I I)$ ions on okra leaves

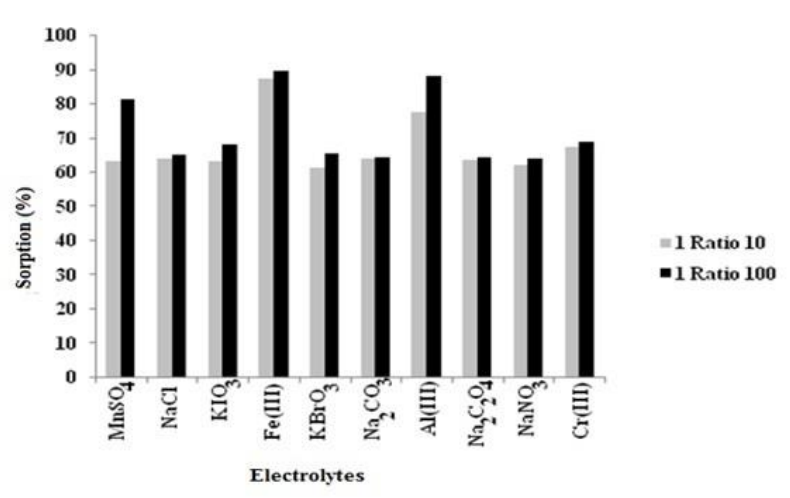


Figure $6 \mathbf{b}$. Electrolytic effect on the sorption of $\mathrm{As}(\mathrm{V})$ ions on okra leaves

\section{Application}

The applicability of the developed method was analyzed by the removal of arsenic ions from real water samples. The real water samples were taken from (sample S1) Karachi Table 5. Removal of arsenic from real water samples
Wah at the draining point of Industrial effluents of the Kotri Site area, District Jamshoro, Pakistan and (sample S2) tube well water near United Ethanol Industry Sadiqabad, District Rahimyar Khan, Pakistan. The Table 5 shows that method was successfully applied in real systems and up to $81.98 \%$ of arsenic was removed.

\begin{tabular}{|c|c|c|c|c|}
\hline Samples & $\begin{array}{l}\text { Original arsenic conc. in sample ( } \mu \mathrm{g} \mathrm{L}^{-} \\
1 \text { ) }\end{array}$ & Amount of arsenic added $\left(\mu \mathrm{g} \mathrm{L}^{-1}\right)$ & \% Recovery & Residual amount $\left(\mu \mathrm{g} \mathrm{L}^{-1}\right)$ \\
\hline 1 & 40.0 & - & 76.5 & 09.40 \\
\hline 2 & 40.0 & 50 & 89.44 & 09.50 \\
\hline 3 & 0.68 & 50 & 71.98 & 09.10 \\
\hline
\end{tabular}

\section{Conclusion}

Okra leaves sorbent proved to be an efficient for the removal of $\mathrm{As}(\mathrm{III})$ and $\mathrm{As}(\mathrm{V})$ from aqueous medium. Sorption reaction of both arsenic species depended on $\mathrm{pH}$ and time. At pH 7.0 and $\mathrm{pH} 6.0$ the maximum uptake of As(III) $5672 \mu \mathrm{g} \mathrm{g}^{-1}$ and $\mathrm{As}(\mathrm{V}) 13160 \mu \mathrm{g} \mathrm{g}^{-1}$ respectively was observed. Equilibrium was achieved in 180 minutes. Freundlich and Flory-Huggins models were employed for the isotherm study. Psuedo second order rate equation and Morris-Weber equation explained the kinetics of sorption reaction. Thermodynamic parameters indicated that sorption reaction was endothermic in nature and proceeded spontaneously. Desorption study revealed that $89.82 \%$ of $\mathrm{As}(\mathrm{III})$ and $97.11 \%$ of $\mathrm{As}(\mathrm{V})$ were removed with $1 \mathrm{M} \mathrm{HCl}$.

\section{References}

Aniruthan T.S. and Unnithan M.R. (2007), Arsenic(V) from aqueous solutions using an anion exchanger derived from coconut coir pith and its recovery, Chemosphere, 66, 60-66.

Aryal M., Ziagova M. and Kyriakides M.L. (2010), Study on arsenic biosorption using $\mathrm{Fe}(\mathrm{III})$-treated biomass of Staphlococcus xylosus, Chemical Engineering Journal, 162, 178-185.

ATSDR (1990), Agency for Toxic Substances and Disease Registry: Case studies in Environmental Medicine, Arsenic Toxicity. U.S. Public Health Services, Atlanta USA, June.

Biswas B.K., Jun-ichi Inoue K., Ghimire K.N., Harada H., Ohto K. and Kawakita H. (2008), Adsorptive removal of $\mathrm{As}(\mathrm{V})$ and $\mathrm{As}(\mathrm{III})$ from water by a $\mathrm{Zr}(\mathrm{IV})$-loaded orange waste gel, Journal of Hazardous Materials, 154, 1066-1074.

Chen R., Zhang Z., Feng C., Hu K., Li M., Shunizu K., Chen N. and Sugiura N. (2010), Application of simplex-centroid mixture design in developing and optimizing ceramic adsorpbent for As(V) removal from water solution, Microporous and Mesoporous Materials, 131, 115-121.

Chen S., Dzeng S.R., Yang M., Chiu K., Shieh G. and Wai C.M. (1994), Arsenic species in ground waters of the Black foot disease area, Taiwan, Environmental Science and Technology, 28, 877-881.

Chen S., Yue Q., Gao B. and Xu X. (2010), Equilibrium and kinetic adsorption study of the adsorptive removal of $\mathrm{Cr}(\mathrm{VI})$ using modified wheat residue, Journal of Colloid and Interface Science, 349, 256-264.
Chen Y.N., Chai L.Y. and Shu Y.D. (2008), Study of arsenic(V) adsorption on bone char from aqueous solution, Journal of Hazardous Materials, 160, 168-172.

Chowdhury M.R.I. and Mulugan C.N.J. (2011), Biosorption of arsenic from contaminated water by anaerobic biomass, Journal of Hazardous Materials, 190, 486-492.

Febrianto J., Kosasih A.N., Sunarso J., Ju Y.H., Indraswati N. and Ismadji S. (2009), Equilibrium and kinetic studies in adsorption of heavy metals using biosorbent: A summary of recent studies, Journal of Hazardous Materials, 162, 616-645.

Ghimiri K.N., Inoue K., Makino K. and Miyajima T. (2002), Adsorption removal of arsenic using orange juice residue, Separation Science and Technology, 37, 2785-2799.

Giri A.K., Patel R.K. and Mahaptra S.S. (2011), Artificial neutral network approach for modeling of As(III) biosorption from aqueous solution by living cells of Bacillius cereus biomass, Chemical Engineering Journal, 178, 15-25.

Haron M.J., Yunus W.M.Z.W., Yong N.L. and Tokunaga S. (1999), Sorption of arsenate and arsenite anions by iron(III)-poly (hydroxamic acid) complex, Chemosphere, 39, 2459-2466.

Ho Y.S. and McKay G. (1998), Kinetic model for lead(II) sorption onto peat, Adsorption Science and Technology, 16, 243-255.

Huang C.P. and Fu P.L.K.J. (1984), Treatment of arsenic(V)containing water by the activated carbon process, Water Pollution and Control Federation, 56, 233-242.

Iftikhar A.R., Bhatti H.N., Hanif M.A. and Nadeem R. (2009), Kinetic and thermodynamic aspects of $\mathrm{Cu}$ (II) and $\mathrm{Cr}$ (III) removal from aqueous solutions using rose waste biomass, Journal of Hazardous Material, 161, 941-947.

Jing C., Mang X., Calvache E. and Jiang G. (2009), Remediation of organic and inorganic arsenic contaminated ground water using a nanocrystalline $\mathrm{TiO}_{2}$-based adsorbent, Environmental Pollution, 157, 2514-2519.

Jnr M.H. and Spiff A.I. (2005), Equilibrium sorption study of $\mathrm{Al}^{3+}$, $\mathrm{Co}^{2+}$ and $\mathrm{Ag}^{2+}$ in aqueous solutions by fluted pumpkin (Telfairia accidentalis HOOK f) waste biomass, Acta Chimica Slovenica, 52, 174-181.

Kamala C.T., Chu K.H., Chary N.S., Pandey P.K., Ramesh S.L., Sastry A.R.K. and Sekhar K.C. (2005), Removal of arsenic(III) from aqueous solution using fresh and immobilized plant biomass, Water Research, 39, 2815-2826.

Khaskheli M.I., Memon S.Q., Chandio Z.A., Jatoi W.B., Mahar M.T. and Khokhar F.M. (2016), Okra leaves-Agricultural wasate for the removal of $\mathrm{Cr}(\mathrm{III})$ and $\mathrm{Cr}(\mathrm{VI})$ from contaminated water, American Journal of Analytical Chemistry, 7, 395. 
Khaskheli M.I., Memon S.Q., Siyal A.N. and Khuhawar M.Y. (2011), Usage of orange peel waste for Arsenic remediation of drinking water, Waste Biomass Valorization, 2, 423-433.

Khaskheli M.I., Memon S.Q., Wahid B.J., Chandio Z.A., Shar G.K., Malik A. and Shaista K. (2017), Competitive sorption of nickel, copper, lead and cadmium on okra leaves (Abelmoschus esculentus), Global Nest Journal, 19, 278-288.

Kiran B. and Kaushik A. (2008), Chromium binding capacity of Lyngbya putealis exopolysaccharides, Biochemical Engineering Journal, 38, 47-54.

Korte N.E. and Fernando Q. (1991), A review of arsenic(III) in ground water, Critical Reviews in Environmental Control, 21, 1-39.

Ladeira A.C.Q. and Ciminelli V.S.T. (2004), Adsorption and desorption of arsenic on an oxisol and its constituents, Water Research, 38, 2087-2094.

Li Z., Mou S., Ni Z. and Riviello J.M. (1995), Sequential dertermination of arsenite and arsenate by ion chromatography, Analytica Chimica Acta, 307, 79-87.

Lorenzen L., Deventer J.S.J.V. and Landi W.M. (1995), Factors affecting the mechanism of the adsorption of arsenic species on activated carbon, Minerals Engineering, 8, 557-569.

Maheshwari S. and Murugesan A.G. (2011), Removal of arsenic(III) ions from aqueous solution using Aspergillius flavus isolated from arsenic contaminated site, Indian Journal of Chemical Technology, 18, 45-52.

Morris W.J. and Weber C. (1963), Kinetics of adsorption on carbon from solution, Journal of the Sanitary Engineering Division, 89, 31-59.

Nadeem R., Ansari T.M. and Khalid A.M. (2008), Fourier transform infrared spectroscopic characterization and optimization of $\mathrm{Pb}$ (II) by fish (Labeo rohita) scales, Journal of Hazardous Materials, 156, 64-73.

National Research Council, Report: (1999), Arsenic in drinking water. National Academy of Sciences, Washington DC.

Pokhrel D. and Viraraghavan T. (2008), Arsenic removal from an aqueous solution by modified $A$. niger biomass: Batch kinetic and isotherm studies, Journal of Hazardous Materials, 150, 818-825.

Rahman M.S., Basu A. and Islam M.R. (2008), The removal of $\mathrm{As}(\mathrm{III})$ and $\mathrm{As}(\mathrm{V})$ from aqueous solutions by waste materials, Bioresource Technology, 99, 2815-2823.

Sari A., Uluozlu O.D. and Tuzen M. (2011), Equilibrium, thermodynamic and kinetic investigations on biosorption of arsenic from aqueous solutions algae (Maugeotia genuflexa) biomass, Chemical Engineering Journal, 167, 155-161.

Shafique U., ljaz A., Salman M., Zaman W., Jamil N., Rehman R. and Javaid A. (2012), Removal of arsenic from water using pine leaves, Journal of Taiwan Institute of Chemical Engineers, 43, 256-263.

Smith A.H. and Smith M.M.H. (2004), Arsenic drinking water regulations in developing countries with extensive exposure, Toxicology, 198, 39-44.

Su T., Guanc B.X., Tanga Y.B., Gub G. and Wanga J. (2010), Predicting competitive adsorption behavior of major toxic anionic elements onto activated alumina: A speciation-based approach, Journal of Hazardous Materials, 176, 466-472.

Tuzen M., Sari A., Mendil D., Uluozlu O.D., Soylak M. and Dogan M. (2009), Characterization of biosorption process of As(III) on green algae, Journal of Hazardous Materials, 165, 566572.
Vijayaraghavan K., Padmesh T.V.N., Palanivelu K. and Velan M. (2006), Biosorption of nickel(II) ions onto Sargassum wightii: application of two-parameter and three-parameter isotherm models, Journal of Hazardous Materials, B133: 304-308. 